\title{
Growth inhibition of human endothelial cells by the phyto-oestrogen biochanin A, a metabolite of genistein
}

\author{
Chingwen Ying ${ }^{*}$, Jih-Tay $\mathrm{Hsu}^{2}$ and Show-Chi Shieh ${ }^{1}$ \\ ${ }^{1}$ Department of Microbiology, Soochow University, Taipei, Taiwan, Republic of China \\ ${ }^{2}$ Department of Animal Sciences, National Taiwan University, Taipei, Taiwan, Republic of China
}

(Received 2 May 2000 - Revised 17 October 2000 - Accepted 29 October 2000)

\begin{abstract}
This study examined the growth regulatory effects of a phyto-oestrogen, biochanin A, on a transformed human endothelial cell line ECV304 in vitro. Biochanin A was found to inhibit cell proliferation in a dose-dependent fashion and this effect was influenced by the concentration of serum present in the culture medium. In the absence of serum, the calculated $\mathrm{IC}_{50}$ of biochanin A was $0 \cdot 18 \pm 0 \cdot 1 \mu \mathrm{M}$ compared to an $\mathrm{IC}_{50}$ of $35 \pm 5 \mu \mathrm{M}$ at $10 \%$ serum. At low cell density, the growth inhibitory effects of biochanin A were more evident than at high cell density. Coadministration of a synthetic oestrogen diethylstilboestrol with biochanin A did not suppress the growth regulatory effects of biochanin A treatment. We conclude that biochanin A inhibits the cell proliferation of human endothelial cells at concentrations that are physiologically achievable in vivo and that this effect may play an important role in the cancer-preventing activity of the phyto-oestrogens.
\end{abstract}

Phyto-oestrogen: Endothelial cells: Cell proliferation

Epidemiological and migrant studies suggest that diet may influence the etiology of certain cancers (Adlercreutz, 1995; Herman et al. 1995). High incidence of the so-called Western diseases, including the major hormone-dependent cancers such as breast, prostate and endometrial cancers, colon cancer and coronary heart disease have been associated with a Western diet (Trowell \& Burkitt, 1981; Rose et al. 1986). Conversely, Asian women and vegetarians are less at risk from these cancers and diseases, apparently because of their high consumption of phytooestrogen-rich products such as dietary soy (Adlercreutz et al. 1982, 1986). Immigrants from Asia who maintain their traditional diet do not increase their risk of these diseases; however, an increased risk for these diseases accompanies a change toward a Westernized diet (Kolonel, 1988; Lee et al. 1991).

Phyto-oestrogens are plant chemicals that are structurally similar to the sex hormone oestrogen (Shutt \& Cox, 1972). Since 1931 it has been well known that soybeans contain high amount of phyto-oestrogens, especially daidzein and genistein (Eldridge \& Kwolek, 1983). When consumed, the phyto-oestrogens undergo metabolic conversions in the gut, which results in the formation of hormone-like compounds (Setchell \& Adlercreutz, 1988). These compounds have been found in the human plasma, urine and faeces
(Adlercreutz, 1995). In vitro experiments have shown that specific phyto-oestrogens inhibit the growth of several tumour cell types, including mammary (Hsu et al. 1999), leukaemia (Honma et al. 1990), prostate (Hempstock et al. 1998) and pancreatic cancer cells (Lyn-Cook et al. 1999). In animals, consumption of phyto-oestrogen-rich soy has been shown to protect rodents from experimentally induced cancers (Barnes et al. 1990; Hawrylewicz et al. 1995). Several possible mechanisms have been proposed for the antitumour activity of phyto-oestrogens, including agonist and antagonist effects on oestrogen receptors (Adlercreutz et al. 1995), stimulation of sex-hormone-binding globulin synthesis (Kurzer \& Xu, 1997), inhibition of growth factorassociated tyrosine-kinase signal transduction (Akiyama et al. 1987), antioxidant properties (Naim et al. 1976), inhibition of DNA topoisomerase (Okura et al. 1988) and antiangiogenic effects (Fotsis et al. 1993).

Angiogenesis, the generation of new capillaries from pre-existing vessels, is virtually absent in the healthy adult organism, in which it is restricted to a few conditions such as wound healing and the formation of corpus, luteum, endometrium, and placenta. These conditions of physiological angiogenesis represent ordered, tightly regulated and self-limited process (Klagsbrun \& Folkman, 1990). Thus, for example in wound healing, the same endothelial cells

\footnotetext{
Abbreviations: DES, diethylstilboestrol; DMSO, dimethylsulphoxide; FBS, fetal bovine serum, HBSS, Hank's balanced salt solution.

* Corresponding author: Dr C. Ying, fax +886-2-2883-1193, email cying@mail.scu.edu.tw
} 
can undergo rapid proliferation during spurts of angiogenesis, followed by long periods of quiescence in which less than $0.1 \%$ of the endothelial cells proliferate (Denekamp, 1990) and the turnover of endothelial cells is measured in thousands of days. However, angiogenesis is dramatically enhanced and loses its self-limiting capacity in certain pathological conditions. For instance, during the development and progression of many diseases, such as rheumatoid arthritis, psoriasis, and diabetic retinopathy, $10 \%$ or more of the endothelial cells actively proliferate (Folkman et al. 1989; Denekamp, 1990). Formation of new blood vessels is also critical for the growth of tumours (Folkman, 1985; Blood \& Zetter, 1990). Avascular tumours do not grow beyond a diameter of 1-2 $\mathrm{mm}$, whereas well vascularized tumours expand both locally and by metastasis (Folkman \& Cotran, 1976; Klagsbrun \& Folkman, 1990). Though the mechanisms leading to persistent pathological angiogenesis are still unclear, recent evidence indicates that it may result from an imbalance between angiogenic factors and inhibitors, with the activity of angiogenic factors being too high and/or that of the inhibitors being reduced or completely absent (Liotta et al. 1991).

The idea that dietary ingested compounds might be able to modulate pathological angiogenesis clearly merits further investigation. If dietary compounds were indeed to inhibit angiogenesis, this could explain, at least in part, the long-known preventive effects of the phyto-oestrogens on tumourigenesis. In this report, we studied the effects of the phyto-oestrogen biochanin A, which can be converted from genistein in animals (Kurzer \& Xu, 1997), on the cell proliferation of transformed human endothelial cells, target cells for angiogenesis. Our results show that biochanin A is able to inhibit cell growth at physiologically achievable concentrations.

\section{Materials and methods}

\section{Chemicals}

Biochanin A was purchased from Sigma Chemical Co. (St. Louis, MO, USA). The cell line ECV304 (CCRC 60077), originally deposited in the American Type Cell Culture Collection, was obtained from the Culture Collection and Research Center of Taiwan. ECV304 is a spontaneously transformed immortal endothelial cell line established from the vein of an apparently normal human umbilical cord. Medium 199 (M199), Hank's balanced salt solution (HBSS), fetal bovine serum (FBS), and an antibioticantimycotic mix were purchased from GIBCO BRL (Gaithersburg, MD, USA). A cell proliferation assay kit (WST-1) was purchased from Boehringer Mannheim Biochemicals (Mannheim, Germany). Solutions of biochanin A and diethylstilboestrol (DES), a synthetic oestrogen agonist, were prepared in dimethylsulphoxide (DMSO) and ethanol respectively and stored at $-20^{\circ} \mathrm{C}$ in the dark.

\section{Cell culture conditions}

The ECV304 cells were grown in M199 containing 0.6\% $N$-(2-hydroxyethyl)piperazine- $N$ '-2-ethanesulphonic acid, and $0.22 \%$ sodium bicarbonate, and supplemented with
$10 \%$ either FBS for routine culture or $3 \times$ dextrancharcoal-stripped FBS for all assays. The $3 \times$ dextrancharcoal-stripped FBS was prepared by passing the FBS through dextran-coated charcoal three times at $4^{\circ} \mathrm{C}$ and then filter sterilized to deplete the steroids, including oestrogens, from the FBS. The purpose of using charcoal-stripped FBS during assays is to reduce the background of steroid-like reactivity in cells, or to 'de-sensitize' cells that were previously cultured in medium supplemented with FBS. Cultures were maintained at $37^{\circ} \mathrm{C}$ in a humidified atmosphere of $95 \%$ air- $5 \% \mathrm{CO}_{2}$ and fed every 2 days.

\section{Proliferation assays}

Cells were seeded in culture flasks in assays that investigated the effects of co-administration of oestrogen and the effects of cell density at indicated cell densities. Cells were grown in 96-well culture plates in the assays that studied the effects of serum concentration. M199 containing $10 \% 3 \times$ dextran-charcoal-stripped FBS was used to culture the ECV304 cells. After a $24 \mathrm{~h}$ preculture period to ensure attachment, the medium was replaced with fresh M199 supplemented with 0-10 \% 3× dextran-charcoalstripped FBS. This replacement medium also contained biochanin A $(0-140 \mu \mathrm{M})$ and, in the assays that investigated the effects of the co-administration of oestrogen, DES at molar concentrations $1 \times, 10 \times$ and $100 \times$ higher than that of the biochanin A was also added. DMSO at the same dilutions, was added to parallel cultures as a control. Final concentrations of DMSO in the culture medium were kept below $1 \%(\mathrm{v} / \mathrm{v})$, which caused no measurable effects on cell growth or cell morphology. At the end of the incubation period (4 days), the number of viable cells in each sample was determined by the trypan blue dye exclusion method for cells grown in flasks. The trypan blue dye exclusion method has been widely used to determine the number of viable cells since viable cells remain transparent under a microscope while non-viable cells appear blue in the presence of trypan blue dye. Briefly, cells were recovered from the flasks, collected by centrifugation and resuspended in a small amount of culture medium. A portion of cell suspension $(90 \mu \mathrm{l})$ was mixed with $10 \mu \mathrm{l}$ of trypan blue dye and the number of apparent cells was counted under the microscope with a haemocytometer.

For cells grown in the 96-well culture plates, cell proliferation was determined by the WST-1 method. Adding $10 \mu \mathrm{l}$ of the WST-1 reagent into each well of 96-well plates and incubated for $4 \mathrm{~h}$ at $37^{\circ} \mathrm{C}$ according to manufacturer's instructions, the number of viable cells can be determined. A succinate-tetrazolium reductase system, which belongs to the respiratory chain of the mitochondria and is active only in viable cells, can cleave the WST-1 salt and form formazan dye. Therefore, the resulting amount of formazan dye can then be directly correlated to the number of metabolically active cells in the culture. The formation of formazan dye which absorbed at the wavelength of $420 \mathrm{~nm}$ was quantitated using a scanning multiwell spectrophotometer (ELISA reader). The absorbance at $420 \mathrm{~nm}$ minus the absorbance at $650 \mathrm{~nm}$, which represented the background, was directly 
correlated to the numbers of viable cells in each sample (Hsu et al. 1999).

\section{Statistical analysis}

The method of least squares ANOVA using the general linear model procedures for a completely randomized design with biochanin A concentration as the treatment factor was used to analyse data (Snedecor \& Cochran, 1980; SAS, 1990) The means of treatment were compared, by orthogonal contrast, with the comparisons of each individual biochanin A concentration $v$. control blank.

\section{Results}

The effects of biochanin A on growth inhibition of ECV304 cells were examined and the results are shown in Fig. 1. In the presence of $10 \% 3 \times$ dextran-charcoal-stripped FBS, biochanin A had a cytostatic effect on the cell proliferation at low concentrations and cytotoxic effects at $105 \mu \mathrm{M}$ and above (Fig. 1a). The calculated $\mathrm{IC}_{50}$ (concentration at which $50 \%$, of the cell growth was inhibited) was $35 \mu \mathrm{M}$. In the absence of FBS (Fig. 1b), the growth inhibitory effects of biochanin A were greatly enhanced: at biochanin $\mathrm{A}$, concentration of $35 \mu \mathrm{M}$, there was $80 \%$ reduction in the number of cells relative to the control, and the $\mathrm{IC}_{50}$ was calculated to be $0.18 \mu \mathrm{M}$. To further examine the effects of the presence of serum, ECV304 cells were incubated with biochanin $\mathrm{A}$ and various percentages of $3 \times$ dextrancharcoal-stripped FBS. As Fig. 2 shows, at all the concentrations of FBS tested, cell proliferation was inhibited in a dose dependent fashion by biochanin $\mathrm{A}$. However, the inhibition sensitivity was greatly enhanced when the FBS was absent. At the lower biochanin A concentrations $(0-70 \mu \mathrm{M})$, the growth rate of cells in the presence of $7.5 \% 3 \times$ dextran-charcoal-stripped FBS was unexpectedly slow (Fig. 2).

Cell density was shown to affect the number of viable ECV304 cells treated with biochanin A (Fig. 3). Cells were first seeded in culture plates at different cell densities and the proper attachment of ECV304 cells at all three cell densities was confirmed microscopically. The ECV304 cells were then treated with biochanin A for 4 days and the number of viable cells in each flask was determined (Fig. 3). At low cell density (approximately $40 \%$ confluence), the number of viable cells was reduced by $86 \%$ in the presence of biochanin A at $55 \mu \mathrm{M}$, whereas, at higher cell densities (65\% and $90 \%$ confluence), the same concentration of biochanin A reduced the number of viable cells by about $67 \%$ (Fig. 3).

Oestrogens are naturally present in animals and the effects of oestrogens must be taken into account if phytooestrogens are to be considered as potential tumourpreventing agents. When the synthetic oestrogen DES was added in molar excess $(1 \times, 10 \times, 100 \times)$ simultaneously with biochanin $\mathrm{A}$ in the presence or absence of $10 \%$ FBS, the effects of biochanin A were modified only slightly (Fig. 4). In the absence of FBS, $0.18 \mu \mathrm{M}$ of biochanin A reduced the number of viable cells to the same degree as when the DES was added (Fig. 4a). A similar observation was obtained when cells were treated with
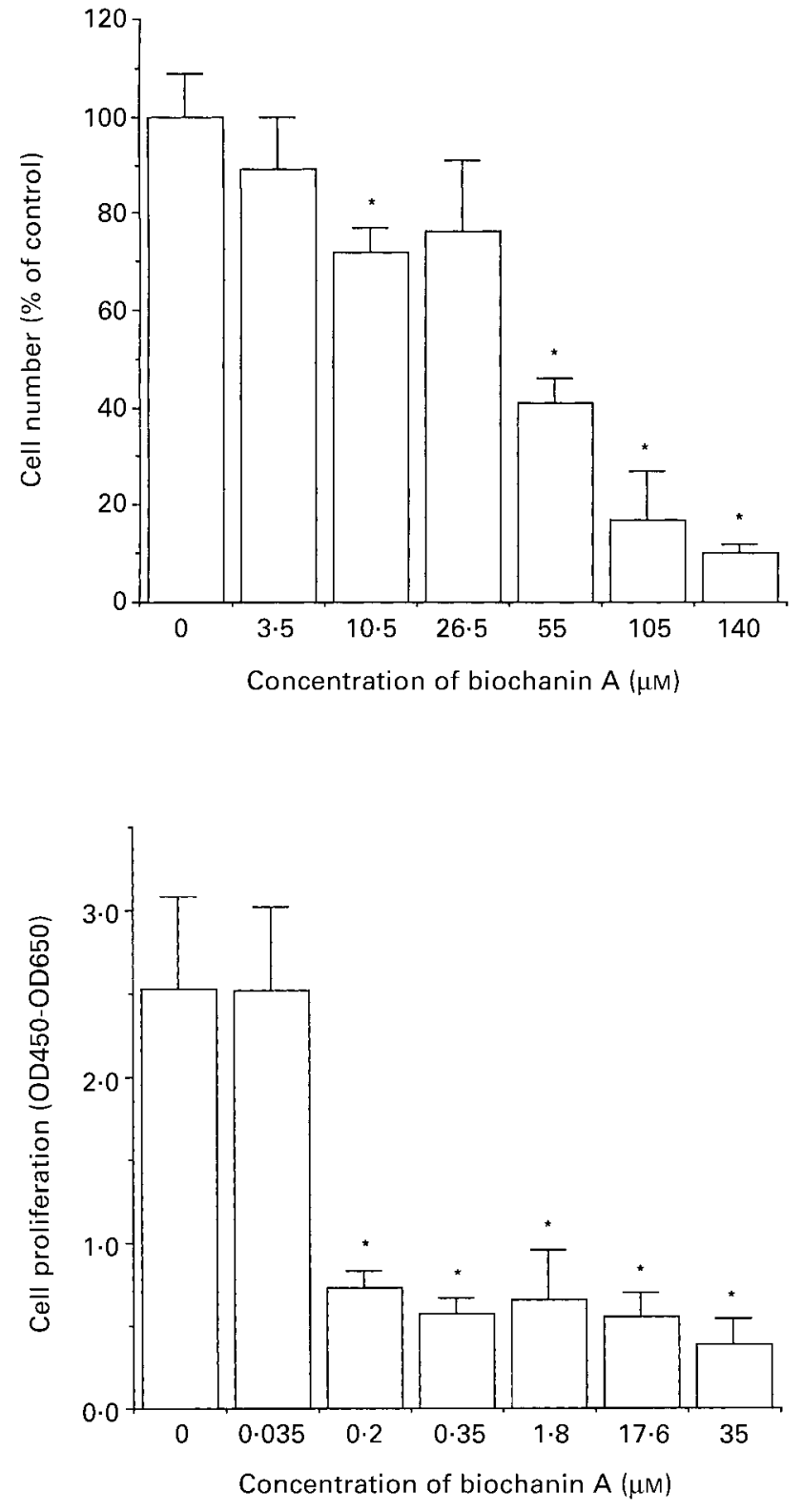

Fig. 1. The effects of biochanin A on the cell proliferation of ECV304 cells. (a) Biochanin A was added at the indicated concentrations to ECV304 cells (initially $9.2 \times 10^{4}$ cells/T-25 flask) in the presence of M199 and $10 \% 3 \times$ dextran-charcoal-stripped FBS. After the cells had been incubated for 4 days at $37^{\circ} \mathrm{C}$ with the indicated concentration of biochanin $A$, the number of cells was determined by the trypan blue dye exclusion method. (b) The ECV304 cells were seeded in 96-well culture plates at $3.4 \times 10^{4}$ per well in M199 without FBS. After $24 \mathrm{~h}$ at $37^{\circ} \mathrm{C}$, fresh M199 medium alone or with biochanin $A$ as indicated was added into each well. Following incubation for 4 days, the number of cells per well was determined by WST-1 assay. Experiments with similar designs were performed four times and the value (mean and SD) with $a^{*}$ indicates significant difference $(P<$ $0.01)$ compared with the DMSO-treated cells $(0 \mu \mathrm{g} / \mathrm{ml}$ biochanin $A)$.

biochanin A and DES simultaneously in the presence of $10 \%$ FBS (Fig. 4b). The inhibitory effect of biochanin A alone or of the combined effects of biochanin A and DES were not different. Administration of DES alone at concentrations starting from a physiological concentration 


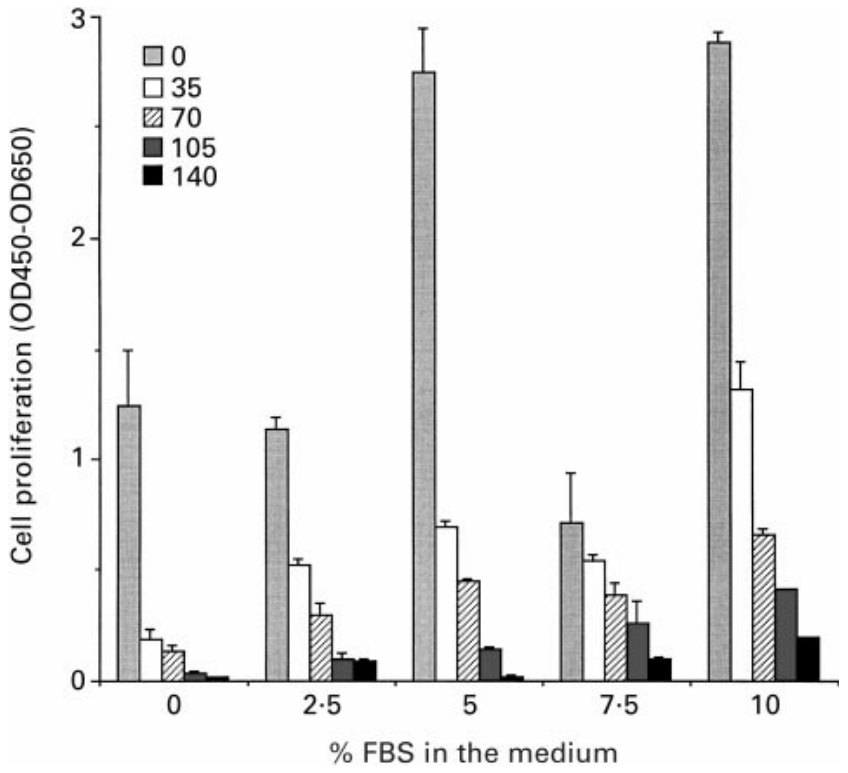

Fig. 2. Serum concentration affects the cell proliferation by biochanin A. ECV304 cells seeded at $2.0 \times 10^{4} /$ well were treated with M199 containing the indicated percentage of $3 \times$ dextran-charcoal-stripped FBS $(0-10 \%)$ alone or with the indicated concentration of biochanin A $(35-140 \mu \mathrm{M})$ for 4 days. The number of cells was determined by WST-1 assay. Experiments were repeated three times and the values are mean and SD.

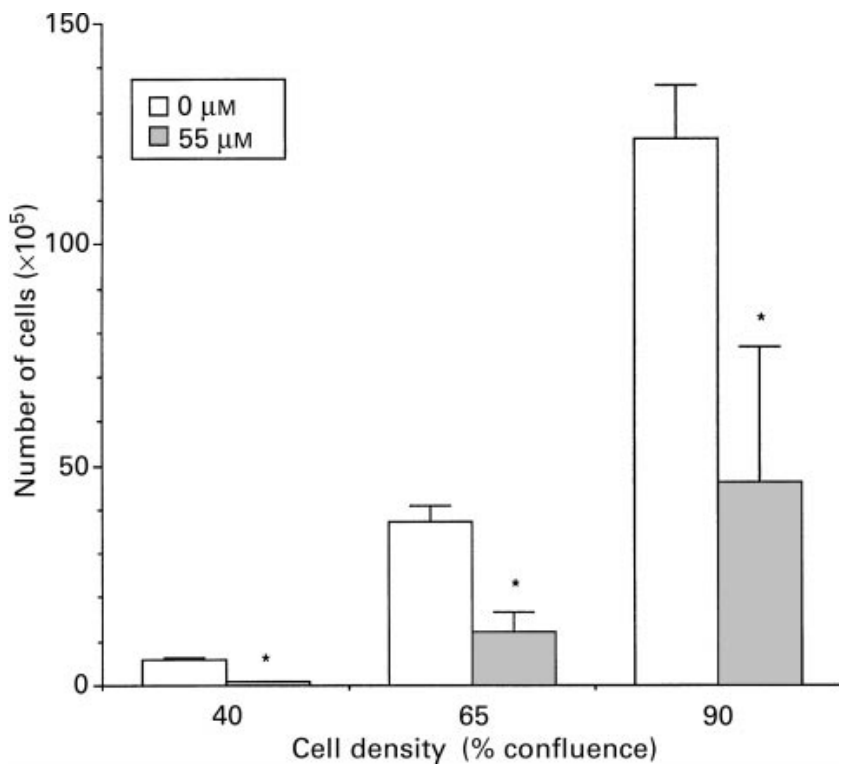

Fig. 3. The growth regulatory effect of biochanin $A$ is influenced by cell density. The ECV304 cells were seeded in T-25 flasks at 40,65 or $90 \%$ cell density respectively. The cells were then incubated with ethanol (indicated as $0 \mu \mathrm{M}$ ) or $55 \mu \mathrm{M}$ biochanin A for 4 days in medium containing $10 \% 3 \times$ dextran-charcoal-stripped FBS, after which the number of viable cells in each flask was determined by trypan blue dye exclusion assay. Similar experiments were performed three times and values are shown as mean and SD. *Indicates significant difference $(P<0.01)$ compared with its respective DMSO-treated cells $(0 \mu \mathrm{g} / \mathrm{ml}$ of biochanin A).
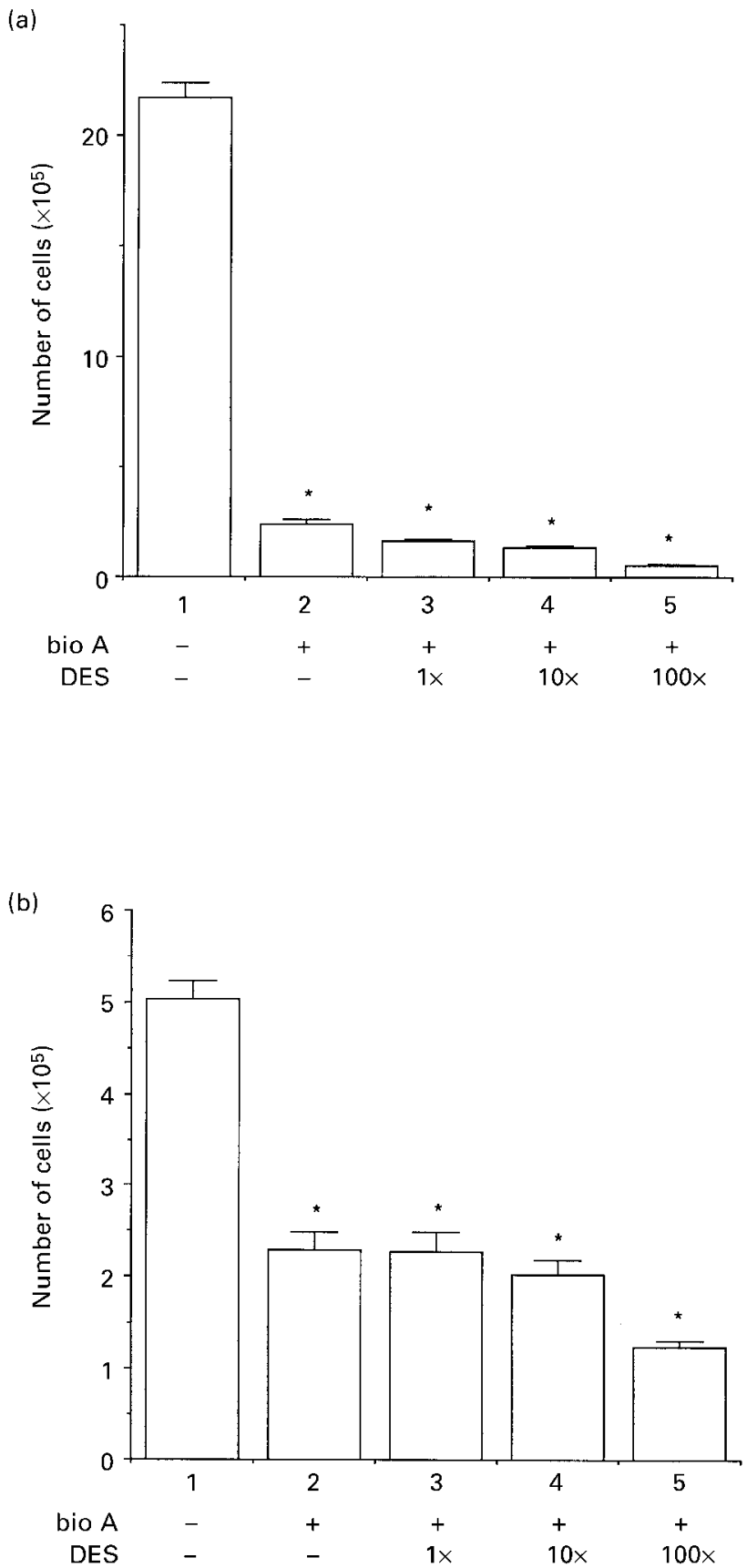

Fig. 4. The effects of co-administration of oestrogen on ECV304 cells treated with biochanin A. (a) Cells were treated with $0.18 \mu \mathrm{M}$ of biochanin A alone (column 2) or with indicated molar excess of DES (columns 3-5) in the absence of FBS. (b) The ECV304 cells were incubated with $55 \mu \mathrm{M}$ of the biochanin $A$ alone (column 2) or with indicated molar excess of DES (column 3-5) in the presence of $10 \% 3 \times$ dextran-charcoal-stripped FBS. DES concentrations were at 1,10 or $100 \times$ molar excess of the treated biochanin $A$ concentration. Viable cells were counted by trypan blue dye exclusion assays after incubation for 4 days. Column 1 represents the control. Experiments with similar designs were performed twice. Values are mean and SD. *Indicates significant difference $(P<0.01)$ compared with control cells $(0 \mu \mathrm{g} / \mathrm{ml}$ of biochanin A and DES). 
of $10 \mathrm{nM}$ to concentrations tested in Fig. 4 did not show any significant effect on the number of viable cells among different treatments, however there is a significant difference between the treatment and control groups $(P<$ 0.01). This therefore suggests that the growth regulatory effects on ECV304 cells by biochanin A were not suppressed, and nor were any synergistic effects observed.

\section{Discussion}

Previous reports have shown that in rats a single oral dose of the phyto-oestrogen genistein in pure form $(20 \mathrm{mg} / \mathrm{kg}$ body weight) or a similar dose of genistein in the form of phyto-oestrogen-rich soy extract resulted in genistein plasma concentrations of $11 \mu \mathrm{M}$ and $4.9 \mu \mathrm{M}$, respectively (Xu et al. 1994; Peterson, 1995). Similarly, after receiving a single dose of phyto-oestrogens of $2.0 \mathrm{mg} / \mathrm{kg}$ of body weight in soy milk, phyto-oestrogen levels in human plasma have been measured at $2 \cdot 2 \mu \mathrm{M}$ (Xu et al. 1994). However, the vast majority of publications that describe the effects of phyto-oestrogens in vitro have reported significant results mostly at concentrations higher than those that are achievable in vivo after oral consumption of soybased foods or products enriched in phyto-oestrogens. Wang \& Kurzer (1998), for instance showed that biochanin A inhibited DNA synthesis at 20-90 $\mu \mathrm{M}$, and Fotsis et al. (1997) showed that the phyto-oestrogens genistein inhibited in vitro angiogenesis at a concentration of $10 \mu \mathrm{M}$. The present study extends those observations; the lowest concentration which was found to exhibit significant growth inhibitory effects in the presence of $10 \%$ serum was $3.5 \mu \mathrm{M}$, which is within the physiologically achievable concentration ranges. Our results therefore show that biochanin A was able to inhibit growth in human endothelial cells at concentrations that are readily achievable in plasma.

In the absence of FBS, the $\mathrm{IC}_{50}$ for biochanin $\mathrm{A}$ was more than 200 times lower $(0 \cdot 18 \mu \mathrm{M} v .35 \mu \mathrm{M})$ than in the presence of $10 \%$ FBS. Zava \& Duwe (1997) have suggested that the bioavailability of phyto-oestrogens at growth-inhibitory concentrations might be substantially lower in the plasma due to binding to factors present in the serum. Our results are consistent with the idea that the effects of biochanin A on cell proliferation might be partially masked or inactivated by factors in the serum. Cell density also appears to influence the effectiveness of the growth regulatory effects caused by biochanin A (Fig. 3). At the concentration tested here $(55 \mu \mathrm{M})$, biochanin A exhibits cytostatic rather than cytotoxic effects, and it was found that the number of viable cells was most strongly reduced in the cells at low $(\sim 40 \%)$ cell density. This presumably reflects the fact that at low cell density, cells were in a more active growth phase; the growth regulatory effects induced by biochanin A would thus have a proportionally greater impact. Wang \& Kurzer (1998) have pointed out that the in vitro growth inhibitory effects of phyto-oestrogen might not be reproducible in vivo because of interference by naturally occurring oestrogen, which is present in serum at concentrations of approximately $0 \cdot 1-1 \mathrm{nM}$. The results shown in Fig. 4, however, suggest that it is likely that the growth regulatory effects of biochanin A would also be evident in vivo because even at the highest concentration of DES tested $\left(5.5 \times 10^{-3} \mathrm{M}\right)$, the growth regulatory effects of biochanin A were not blocked. No blocking of the inhibitory effects of biochanin A by DES was found either in the presence or absence of serum.

Recently, much interest has been focused on the possible cancer-protective role of the hormone-like phyto-oestrogens; in vitro inhibition of cancer incidence or progression by soy products or pure phyto-oestrogens has been reported for gastric cancer, leukaemia cells, breast cancer and other cancers (Matsukawa et al. 1993; Hempstock et al. 1998; Wang \& Kurzer, 1998; Lyn-Cook et al. 1999). Histological examination has shown that the consumption of soy products significantly reduced tumour cell proliferation, increased apoptosis and reduced microvessel density (Zhou et al. 1999); and a possible mechanism has also been suggested by the interesting observation that the angiogenic protein insulin-like growth factor-I was reduced in the circulation of mice fed soy protein and phytochemical concentrate (Zhou et al. 1999). However, several studies have found that soy-based dietary treatments had tumourpromoting effects (Makela et al. 1994; Wang \& Kurzer, 1998; Hsu et al. 1999). Under some conditions, oestrogenic properties of the phyto-oestrogens stimulated the growth of human breast cancer cell in vitro. Also increased colon tumour incidence and tumour burden in rats treated by chemical carcinogens were observed when a soybean-based diet or pure phyto-oestrogens were given to these animals (McIntosh et al. 1995; Rao et al. 1997). In the present study on transformed human endothelial cells, no growth stimulatory effects induced by biochanin A were detected at any of the concentrations tested. Despite the encouraging results presented here, however, much more work clearly remains to be done before soy supplements enriched in phyto-oestrogen can be universally recommended for cancer prevention.

\section{References}

Adlercreutz H (1995) Phytoestrogens: epidemiology and a possible role in cancer protection. Environmental Health Perspective 103, 103-112.

Adlercreutz H, Fotsis T, Heikkinen R, Dwyer JT, et al. (1982) Excretion of the lignans enterolactone and enterodiol and of equol in omnivorous and vegetarian postmenopausal women and in women with breast cancer. Lancet 2, 1295-1299.

Adlercreutz H, Fotsis T, Bannwart C, Wahala K, et al. (1986) Determination of urinary lignans and phytoestrogen metabolites, potential antiestrogens and anticarcinogens, in urine of women on habitual diets. Journal of Steroid Biochemistry 25, 791-797.

Adlercreutz CH, Goldin BR, Gorbach SL, Hockerstedt KA, Watanabe S, Hamalainen EK, Markkanen MH, Makela TH, Whala KT, Hase TA \& Fotsis T (1995) Soybean phytoestrogen intake and cancer risk. Journal of Nutrition 125, 757s-770s.

Akiyama T, Ishida J, Nakagawa S, Itoh N, Shibuya M \& Fukami Y (1987) Genistein a specific inhibitor of tyrosine-specific protein kinases. Journal of Biological Chemistry 262, 5592-5595.

Barnes S, Grubbs C, Setchell KD \& Carlson J (1990) Soybeans inhibit mammary tumors in models of breast cancer. Progression of Clinical Biological Research 347, 239-253.

Blood CH \& Zetter BR (1990) Tumor interactions with the 
vasculature: angiogenesis and tumor metastasis. Biochimia Biophysical Acta 1032, 89-118.

Denekamp J (1990) Vascular attack as a therapeutic strategy for cancer. Cancer Metastasis Review 9, 267-282.

Eldridge A \& Kwolek WF (1983) Soybean isoflavones: effect of environment and variety on composition. Journal of Agriculture and Food Chemistry 31, 394-396.

Folkman J (1985) Tumor angiogenesis. Advanced Cancer Research 43, 175-203.

Folkman J \& Cotran RS (1976) Relation of vascular proliferation to tumor growth. International Review of Experimental Pathology 16, 207-248.

Folkman J, Walson K, Ingber D \& Hanahan D (1989) Induction of angiogenesis during the transition from hyperplasia to neoplasia. Nature 339, 58-61.

Fotsis T, Pepper M, Adlercreutz H, Fleischmann G, Hase T, Montesano R \& Schweigerer L (1993) Genistein, a dietaryderived inhibitor of in vitro angiogenesis. Proceedings of National Academic Science USA 90, 2690-2694.

Fotsis T, Pepper MS, Aktas E, Breit S, Rasku S, Adlercreutz H, Wahala K, Montesano R \& Schweigerer L (1997) Flavonoids, dietary-derived inhibitors of cell proliferation and in vitro angiogenesis. Cancer Research 57, 2916-2921.

Hawrylewicz EJ, Zapata JJ \& Blair BH (1995) Soy and experimental cancer: animal studies. Journal of Nutrition 125, 698s-708s.

Hempstock J, Kavanagh JP \& George NJR (1998) Growth inhibition of prostate cell lines in vitro by phyto-oestrogens. British Journal of Urology 82, 560-563.

Herman C, Adlercreutz T, Goldin BR, Gorbach SL, Hockerstedt KAV, Watansbe S, Hamalainen EK, Markkanen MH, Makela TH, Wahala KT, Hase AT \& Fotsis T (1995) Soybean phytoestrogen intake and cancer risk. American Institute of Nutrition 125, 757s-770s.

Honma Y, Okabe-Kado J, Kasukabe T, Hozumi M \& Umezawa K (1990) Inhibition of $u b l$ oncogenic tyrosine kinase induces erythroid differentiation of human myelogenous leukemia K562 cells. Journal of Cancer Research 81, 1132-1136.

Hsu J, Hung H, Chen C, Hsu W \& Ying C (1999) Effects of the dietary phytoestrogen biochanin $\mathrm{A}$ on cell growth in the mammary carcinoma cell line MCF-7. Journal of Nutritional Biochemistry 10, 510-517.

Klagsbrun M \& Folkman J (1990) In Peptide Growth Factors and Their Receptors II, pp. 549-586 [MB Sporn and AB Roberts, editors]. Berlin: Springer-Verlag.

Kolonel LN (1988) Variability in diet and its relation to risk in ethnic and migrant groups. Basic Life Science 43, 129-135.

Kurzer MS \& Xu X (1997) Dietary phytoestrogens. Annual Review of Nutrition 17, 353-381.

Lee HP, Courley L \& Duffy SW (1991) Dietary effects on breast cancer risk in Singapore. Lancet 337, 1197-1200.

Liotta LA, Steeg PS \& Stetler-Stevenson WC (1991) Cancer metastasis and angiogenesis: An imbalance of positive and negative regulation. Cell 64, 327-336.

Lyn-Cook BD, Stottman HL, Yan Y, Blann E, Kadlubar FF \& Hammons GJ (1999) The effects of phytoestrogen on human pancreatic tumor cells in vitro. Cancer Letters 142, 111-119.
Makela S, Davis VL, Tally WC, Korkman J \& Salo L, et al. (1994) Dietary estrogen acts through estrogen receptormediated processes and shows no antiestrogen in cultured breast cancer cells. Environmental Health Perspective 102, 572-578.

Matsukawa Y, Marui N, Sakai T, Satomi Y, Yoshida K, Matsumoto K, Nishino H \& Aoike A (1993) Genistein arrests cell cycle progression at G(2)-M. Cancer Research 53, 1328 1331.

McIntosh GH, Regester GO, Le Leu RK, Royle PJ \& Smithers GW (1995) Dairy proteins protect against dimethylhydrazineinduced intestinal cancers in rats. Journal of Nutrition 125, 809-816.

Naim M, Geststner B, Bondi A \& Birk Y (1976) Antioxidative and antihemolytic activities of soybean isoflavone. Journal of Agriculture and Food Chemistry 24, 1174-1177.

Okura A, Arakawa H, Oka H, Yoshinari T \& Monden Y (1988) Effect of genistein on topoisomerase activity and on the growth of [VAL12]Ha-ras-transformed NIH 3T3 cells. Biochemistry and Biophysics Research Communication 157, 183-189.

Peterson G (1995) Evaluation of the biochemical targets of genistein in tumor cells. Journal of Nutrition 125, 784s-789s.

Rao CV, Wang C-X, Simi B, Lubet R, Kelloff G, Steele V \& Reddy BS (1997) Enhancement of experimental colon cancer by genistein. Cancer Research 57, 3717-3722.

Rose DP, Boyar AP \& Wynder EL (1986) International comparison of mortality rates for cancer of the breast, ovary, prostate, and per capita food consumption. Cancer 58, 23632371.

SAS (1990). SAS/STAT ${ }^{\circledR}$ User's Guide (Release 6.04) Vol. 2, SAS Inst. Inc., Cary, NC, USA.

Setchell KDR \& Adlercreutz H (1988) Mammalian lignans and phytoestrogens. Recent studies on their formation, metabolism and biological role in health and disease. In Role of the Gut Flora in Toxicity and Cancer, pp. 315-345 [I Rowland, editor]. London: Academic Press.

Snedecor GW \& Cochran WG (1980) Statistical Methods. 7th ed. Ames, IA: Iowa State University Press.

Shutt DA \& Cox RI (1972) Steroid and phytoestrogen binding to sheep uterine receptors in vitro. Endocrinology 52, 299-310.

Trowell HC \& Burkitt DP (1981) Western Diseases: Their Emergence and Prevention. London: Edward Arnold Ltd.

Wang C \& Kurzer MS (1998) Effects of phytoestrogen on DNA synthesis in MCF-7 cells in the presence of estradiol or growth factors. Nutrition and Cancer 31, 90-100.

Xu X, Wang H-J, Murphy PA, Cook L \& Hendrich S (1994) Daidzein is a more bioavailable soymilk isoflavone than is genistein in adult women. Journal of Nutrition 124, 825-832.

Zhou JR, Gugger ET, Tanaka T, Guo Y, Blackburn GL \& Clinton SK (1999) Soybean phytochemicals inhibit the growth of transplantable human prostate carcinoma and tumor angiogenesis in mice. Journal of Nutrition 129, 1628-1635.

Zava DT \& Duwe G (1997) Estrogenic and antiproliferative properties of genistein and other flavonoids in human breast cancer cells in vitro. Nutrition and Cancer 27, 31-40. 